\title{
ENSINO RELIGIOSO, UMA HERANÇA DO AUTORITARISMO
}

JOSÉ VAIDERGORN ${ }^{*}$

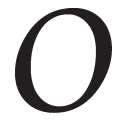

desejo de influência preponderante da religião sobre o Estado e a sociedade não é novidade no Brasil. Depois do Império, onde o padroado estabeleceu o vínculo entre o poder monárquico e o catolicismo como religião oficial, a República, mesmo estando constitucionalmente separada da Igreja, desta sempre sofreu, de forma mais ou menos explícita, a pressão ideológica pelo comando de coraçóes e mentes de seus cidadãos.

Nos tempos mais recentes, de recrudescimento do fundamentalismo religioso de diversas confissóes em todo o mundo (com a conseqüente intolerância que legitima a violência e o terror contra os inimigos de sua fé), a disputa entre as crenças ocupa cada vez maiores espaços. Em suas devidas peculiaridades, o Brasil faz parte desse movimento, e a educação é dele parcela estratégica. Nesse aspecto, é possível traçar uma linha de continuidade desde a República Velha, que passa pelo período da ditadura getulista, pelo interregno democrático de 1945 a 1964, pela imposição da infame Educação Moral e Cívica na ditadura militar, até chegar à concorrência religiosa nas escolas públicas em pleno regime democrático. ${ }^{1}$

As concessões atuais se verificam desde o preâmbulo da Constituição em vigor, promulgada "sob a proteção de Deus". O comprometimento do Estado laico com as influências religiosas no âmbito educacional se mostra, por exemplo, no parágrafo $1^{\circ}$ do artigo $210 \mathrm{da}$ Constituição ("O ensino religioso, de matrícula facultativa, constituirá

Doutor em Educação e professor do Departamento de Ciências da Educação e do Programa de Pós-Graduação em Educação Escolar, da Faculdade de Ciências e Letras da Universidade Estadual Paulista (UNESP - Araraquara).E-mail: mehrlicht@superig.com.br 
disciplina dos horários normais das escolas públicas de ensino fundamental") e é reforçado no artigo 33 da Lei n. 9.293/1996, de Diretrizes e Bases da Educação: "O ensino religioso, de matrícula facultativa, é parte integrante da formação básica do cidadão e constitui disciplina dos horários normais das escolas públicas de ensino fundamental, assegurado o respeito à diversidade cultural religiosa do Brasil, vedadas quaisquer formas de proselitismo". Os parágrafos deste artigo " $\$ 1^{\circ}$ Os sistemas de ensino regulamentarão os procedimentos para a definição dos conteúdos do ensino religioso e estabelecerão as normas para a habilitação e admissão dos professores; $\$ 2^{\circ}$ - Os sistemas de ensino ouvirão entidade civil, constituída pelas diferentes denominaçôes religiosas, para a definição dos conteúdos do ensino religioso"), bem como o proposto pelos Parâmetros Curriculares Nacionais (PCN) de 1998, tentam aparentemente se esforçar em evitar o inevitável.

Nos Parâmetros, os temas transversais trazem um discurso que ressalta a pluralidade e o respeito às diferenças e desigualdades para se alcançar a igualdade. A proposição de respeito aos diversos costumes, origens e dogmas religiosos na valorização da alteridade, belas palavras que recheiam os Parâmetros, encobre o embate que restaura o que havia de mais autoritário e conservador na educação do período da ditadura militar.

Sob a denominação de Educação Moral e Cívica, como disciplina e área de estudo, implantada em 1969, os pressupostos da moral conservadora e do civismo religioso, agregados aos valores da Doutrina de Segurança Nacional portados pelo "regime militar", passaram a compor os conteúdos escolares garantidores dos "objetivos nacionais permanentes" dos vencedores de 1964. A formação desejada era a de uma boa cidadania, que se moveria em um mundo binário e maniqueísta (certo/errado, sim/não, bom/mau etc.), favorecendo assim uma concepção de poder. Seus pressupostos, zelados por uma Comissão Nacional de Moral e Civismo, eram o de controle e submissão, notadamente sobre o proletariado, clientela privilegiada das escolas públicas e potencialmente ameaçadora aos setores dominantes do Estado e da sociedade, da política e da economia. Os professores, mesmo obtendo uma formação universitária que dava a autorização para o exercício do magistério nas matérias relacionadas (Educação Moral e Cívica e Organização Social e Política do Brasil - OSPB), deveriam apresentar, para 
poderem assumir as aulas nas escolas públicas, cartas de recomendação e atestados de bons antecedentes políticos e criminais.

A realidade construída pela Educação Moral e Cívica era transfigurada ideologicamente através de um processo racionalizador não-científico, que desestruturava as contradições sociais em um mundo imaginário. Apesar do fim da ditadura e da extinção (ou suspensão?) dos conteúdos da moral e cívica como disciplina, as sementes autoritárias continuaram brotando e o ensino religioso, sendo obrigatório no sistema educacional, embora facultativo aos estudantes, conforme a Constituição e a LDB, encontrou terreno fértil.

Reportagem de capa da revista Época (“Jesus vai à escola”) descreve algumas das práticas realizadas em escolas públicas, em diferentes partes do país, por professores que enaltecem o ensino religioso como controlador dos conflitos entre os alunos. À aparência de harmonização e disciplina que seus rituais trariam à escola, contrapõese a disputa pela hegemonia que transcende a fé. Os professores, recrutados a partir de diferentes critérios estaduais, devem ser indicados ou, no mínimo, credenciados por entidades religiosas - lembrando os atestados de antecedentes da época da ditadura. Sendo o catolicismo ainda a religião majoritária, ${ }^{2}$ é natural que as escolas públicas reproduzam, em sua maioria, esta concepção. A história do catolicismo não é meritória em termos de tolerância com as outras crenças. A reportagem mostra, nesse aspecto, quão distante está a prática escolar com o preconizado pelos Parâmetros Curriculares Nacionais. Em diferentes situações, as crianças pertencentes a famílias de credos minoritários ou sem religião são sujeitas ao proselitismo e ao preconceito, ${ }^{3}$ gerando situaçôes de constrangimentos e conflitos dentro e fora da escola.

Não há, a rigor, uma fórmula de tratamento do ensino religioso nas escolas públicas. É um campo aberto de disputa que invade e transcende a vida privada e pretende impor um molde de sociedade de base confessional. E isso se faz tanto de forma pouco refinada - com a quase inocente prática de se orar o Pai Nosso antes das aulas -, como através de um lustro intelectual, de semiformação (Halbbildung) adorniana, como as proposiçôes trazidas, sob a forma de subsídios formativos aos professores, em obras como Ensino religioso no ensino fundamental, produzido por integrantes de três grupos de pesquisa ${ }^{4}$ voltados a este conteúdo e destinado aos professores. 
Em seus cinco capítulos (precedidos de uma apresentação e uma introdução e concluídos com uma curta "Consideraçôes Finais"), os autores do livro pretendem contribuir para a constituição de uma proposta de ensino religioso que siga a linha traçada pelos PCN e incentive aos "outros tecelóes e pesquisadores" a colaborar "para a formação de um mundo melhor e possível” (p. 21-22). O primeiro capítulo, sob um título de inspiração fenomenológica ("O humano religioso: um ser de buscas ou em buscas?"), relaciona a religiosidade com o olhar moderno de mundo. Busca-se encontrar, dessa forma, o lugar do ensino religioso, que deveria dar um sentido à vida e, por extensão, à educação. Após um passeio por citações fragmentadas e resumidas de personagens como Comte, Spencer, Jung, Freud, Fromm, Einstein e, last but not least, Teillard de Chardin, entre outros, o capítulo fecha com uma relação de oito referenciais que podem conduzir a uma proposta de ensino religioso a partir do cotidiano escolar.

O segundo capítulo- "Contexto histórico-cultural do ensino religioso" - inicia com um histórico deste ensino, adentrando na legislação recente que o considera como área do conhecimento e, posteriormente, como disciplina. $\mathrm{Na}$ seqüência, pretende-se inserir o ensino religioso no contexto da escola, no Brasil e no exterior. O capítulo seguinte - "Religiosidade e fenômeno religioso" - é o cerne filosófico da obra, sua razão de ser. Com um discurso teoricamente mais elaborado, se comparado com o restante do livro, os autores expõem ao leitor, iniciando no referencial fenomenológico, a necessidade cultural do sagrado na vida dos povos, na forma de um programa de estudo comparativo.

A conseqüência é óbvia: o quarto capítulo - "Ensino religioso como componente curricular" - apresenta o programa de estudo, definindo o objeto e os objetivos, o conteúdo e a metodologia, a linguagem religiosa a ser utilizada e a identidade e formação do professor. O quinto capítulo - "O ensino religioso e a trans, a inter e a disciplinaridade: uma perspectiva didática" - pretende assumir uma característica multirreferencial, por meio de rasas fórmulas (não é gratuita a citação de Paulo Freire) tão ao gosto dos professores que não sabem - ou não querem - preparar-se para a sala de aula.

A tradição autoritária persiste no ensino religioso. Por mais que se queira atualizar, renovar e descaracterizar sua gênese, permanece o 
intento das religióes de influir na sociedade civil e nos poderes da República, através da educação. A fé, que, na promessa iluminista, deveria se manter no âmbito privado, cada vez mais, no mundo e no Brasil, se torna fator de política pública, por vezes combatendo a razão e o conhecimento científico e legitimando ações antidemocráticas - tal como na época da ditadura.

\section{Notas}

1. Convém lembrar aqui os artigos sobre este tema publicados nos Cadernos de Pesquisa da Fundação Carlos Chagas (São Paulo, v. 37, n. 131, p. 281-369, maio-ago. 2007).

2. A reportagem cita dados do IBGE, onde $74 \%$ da população brasileira se declararam católicos, 15\% evangélicos, $7 \%$ sem religião e 3\% adeptos de outras crenças.

3. Há que se considerar, de acordo com a reportagem, que o estado do Rio de Janeiro adotou, em 2002, no governo Garotinho, uma divisão das práticas de ensino religioso de acordo com a crença dos alunos, incluindo, além dos ritos católico e evangélico, o espiritismo e a umbanda.

4. Grupos de Pesquisa "Educação e Religião" (Curitiba, PR), "Educogitans” (FURB Blumenau, SC) e "Ethos, Alteridade e Desenvolvimento" (FUrB - Blumenau, SC). Como autores, assinam Lilian Blank de Oliveira, Sérgio Rogério Azevedo Junqueira, Luiz Alberto Souza Alves e Ernesto Jacob Keim.

\section{Referências}

ADORNO, T.W. Teoria da semiformação. Trad. de Newton Ramosde-Oliveira, Bruno Pucci e Cláudia B. M. de Abreu. Educação \& Sociedade, Campinas, ano 17, n. 56, p. 388-411, dez. 1996.

ARANHA, A.; MENDONÇA, M. Jesus vai à Escola. Época, São Paulo, n. 537, p. 108-14,1 ${ }^{\circ}$ set. 2008.

OLIVEIRA, L.B. et al. Ensino religioso no ensino fundamental. São Paulo: Cortez, 2007. 175p. (Coleção Docência em Formação - série Ensino Fundamental). 